\title{
Sulfur dioxide inhibits vascular smooth muscle cell proliferation via suppressing the Erk/MAP kinase pathway mediated by cAMP/PKA signaling
}

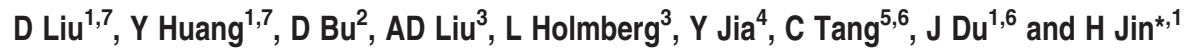

The present study was designed to investigate the role of endogenous sulfur dioxide $\left(\mathrm{SO}_{2}\right)$ in vascular smooth muscle cell (VSMC) proliferation, and explore the possible role of cross-talk between cyclic adenosine monophosphate (cAMP)/protein kinase $A$ (PKA) and extracellular signal-regulated kinase (Erk)/mitogen-activated protein kinase (MAPK) pathways in this action. By cell counting, growth curve depict, flow cytometry and bromodeoxyuridine (BrdU) labeling assays, we found that $\mathrm{SO}_{2}$ inhibited VSMC proliferation by preventing cell cycle progression from G1 to $S$ phase and by reducing DNA synthesis. $\mathrm{SO}_{2}$ synthase aspartate aminotransferase (AAT1 and AAT2) overexpression significantly inhibited serum-induced proliferating cell nuclear antigen (PCNA) protein expression in VSMCs, demonstrated by western blot analysis. Moreover, overexpression of AAT1 or AAT2 markedly reduced incorporation of BrdU in serum-treated VSMCs. By contrast, either AAT1 or AAT2 knockdown significantly exacerbated serum-stimulated VSMC proliferation. Thus, both exogenous- and endogenous-derived $\mathrm{SO}_{2}$ suppressed serum-induced VSMC proliferation. However, annexin V-propidium iodide (PI) staining and cell cycle analysis demonstrated that $\mathrm{SO}_{2}$ did not influence VSMC apoptosis in the serum-induced proliferation model. In a platelet-derived growth factor (PDGF)-BB-stimulated VSMC proliferation model, $\mathrm{SO}_{2}$ dephosphorylated the active sites of Erk1/2, MAPK kinase $1 / 2$ and RAF proto-oncogene serine/threonine-protein kinase (c-Raf) induced by PDGF-BB. However, the inactivation of the three kinases of the Erk/MAPK pathway was not due to the separate interferences on them by $\mathrm{SO}_{2}$ simultaneously, but a consequence of the influence on the upstream activity of the c-Raf molecule. Hence, we examined the cAMP/PKA pathway, which could inhibit Erk/MAPK transduction in VSMCs. The results showed that $\mathrm{SO}_{2}$ could stimulate the $\mathrm{cAMP} / P K A$ pathway to block c-Raf activation, whereas the Ser259 site on c-Raf had an important role in $\mathrm{SO}_{2}$-induced suppression of Erk/MAPK pathway. The present study firstly demonstrated that $\mathrm{SO}_{2}$ exerted a negative regulation of VSMC proliferation via suppressing the Erk/MAPK pathway mediated by CAMP/PKA signaling.

Cell Death and Disease (2014) 5, e1251; doi:10.1038/cddis.2014.229; published online 22 May 2014

Subject Category: Experimental Medicine

\begin{abstract}
Vascular smooth muscle cells (VSMCs), as the major component of tunica media, have an irreplaceable role in vascular morphogenesis and development during embryogenesis and in vascular diseases such as hypertension, diabetes, atherosclerosis and restenosis after rapid response to blood vessel injuries. ${ }^{1-3}$ When resting VSMCs get stimulated by growth factors, they become capable of initiating proliferation. For instance, the binding of plateletderived growth factor (PDGF) to its specific receptor tyrosine kinase (RTK) at the surface of the VSMC membrane activates ras, which triggers the extracellular signal-regulated kinase (Erk)/mitogen-activated protein kinase (MAPK) signal transduction, resulting in cell cycle suppression by inactivating
\end{abstract}

MYT1, which restrains cell cycle progression, accelerating p27Kip1 degradation to activate cyclin E/Cdk2 and inducing cyclin D1 transcription to raise DNA synthesis by regulating Cdk4 and Cdk6. This will eventually lead to cell cycle progression. $^{4-7}$

The endogenous gaseous signaling molecules exert important function in the cardiovascular system. ${ }^{8-12}$ It was reported that the gasotransmitter hydrogen sulfide $\left(\mathrm{H}_{2} \mathrm{~S}\right)$ could alleviate vascular remodeling in several blood vessel injury models, ${ }^{13-15}$ probably by inhibiting VSMC proliferation via Erk/MAPK pathway. ${ }^{16-18}$ Another gasotransmitter that shares the same substrates, sulfur-containing amino acids, with $\mathrm{H}_{2} \mathrm{~S}$ is sulfur dioxide $\left(\mathrm{SO}_{2}\right)$, which can also be

\footnotetext{
${ }^{1}$ Department of Pediatrics, Peking University First Hospital, Beijing, People's Republic of China; ${ }^{2}$ Central Laboratory, Peking University First Hospital, Beijing, People's Republic of China; ${ }^{3}$ Department of Medical and Health Sciences, Linköping University, Linköping, Sweden; ${ }^{4}$ Centre of Medical and Health Analysis, Peking University Health Science Center, Beijing, People's Republic of China; ${ }^{5}$ Department of Physiology and Pathophysiology, Peking University Health Science Center, Beijing, People's Republic of China and ${ }^{6}$ Key Laboratory of Molecular Cardiology, Ministry of Education, Beijing, People's Republic of China

*Corresponding author: H Jin, Department of Pediatrics, Peking University First Hospital, Xi-An Men Street No. 1, West District, Beijing 100034, China. Tel: +86 10 83573209; Fax: +86 10 66530532; E-mail: jinhongfang51@126.com

${ }^{7}$ These authors contributed equally to this work.

Keywords: sulfur dioxide; vascular smooth muscle cell; proliferation; Erk/MAP kinase; cAMP/PKA

Abbreviations: $\mathrm{SO}_{2}$, sulfur dioxide; VSMC, vascular smooth muscle cell; cAMP, cyclic adenosine monophosphate; PKA, protein kinase A; Erk, extracellular signalregulated kinase; MAPK, mitogen-activated protein kinase; BrdU, bromodeoxyuridine; AAT, aspartate aminotransferases; PCNA, proliferating cell nuclear antigen; PDGF, platelet-derived growth factor; MEK, mitogen-activated protein kinase kinase; RTK, receptor tyrosine kinase; $\mathrm{H}_{2} \mathrm{~S}$, hydrogen sulfide; AC, adenylate cyclase; $\mathrm{CDO}$, cysteine dioxygenase; FBS, fetal bovine serum; $\mathrm{PI}$, propidium iodide

Received 29.11.13; revised 18.4.14; accepted 22.4.14; Edited by G Melino
} 
endogenously generated. ${ }^{19-21}$ However, whether and how $\mathrm{SO}_{2}$ regulates VSMC proliferation has not yet been revealed.

Cyclic adenosine monophosphate (cAMP)/protein kinase A (PKA) can initiate apoptosis by inducing p53 and p21 transcriptions in the suppression of human aortic smooth muscle cells, ${ }^{22}$ and it can also prevent growth factor-stimulated Erk/MAPK from being activated in VSMCs. ${ }^{23,24}$ The target of cAMP/PKA signaling on the Erk/ MAPK pathway is c-Raf kinase. PKA can phosphorylate the Ser43, Ser233, Ser259 and Ser621 sites in c-Raf, which blocks the Erk/MAPK cascade. ${ }^{25-27}$ The negative regulation in c-Raf activity mediated by Ser621 phosphorylation by PKA was only observed in in vitro experiment, whereas the other three sites played their negative roles in both in vivo and in vitro studies. ${ }^{25,27}$ Ser43 is located in a separate domain from Ser233 and Ser259, which means that these sites can work independently of each other to obstruct c-Raf activation by disturbing the interaction between c-Raf and ras. ${ }^{25,26}$

It has been reported that the vasorelaxing effect of $\mathrm{SO}_{2}$ is correlated with the prostacyclin/adenylate cyclase (AC)/ CAMP/PKA pathway, ${ }^{28}$ suggesting a potential connection between $\mathrm{SO}_{2}$ and the cAMP/PKA pathway. Therefore, the present study was undertaken to explore the role of $\mathrm{SO}_{2}$ in the regulation of VSMC proliferation and the signal-transduction pathways in its regulatory process.

\section{Results}

$\mathrm{SO}_{2}$ derivatives inhibited serum-stimulated VSMC proliferation. The viability of VSMCs cultured in low-serum medium was not influenced by $\mathrm{SO}_{2}$ derivatives at concentrations of $5,10,15,20,50$ and $100 \mu \mathrm{mol} / \mathrm{l}$ for $24 \mathrm{~h}$, evaluated via CCK-8 assay (Figure 1a), whereas under serumstimulated proliferation conditions, all of the doses of $\mathrm{SO}_{2}$ derivatives described above could significantly inhibit VSMC proliferation (all $P<0.01$; Figure 1a). The latter was also confirmed by depicting the cell growth curve, which showed that $\mathrm{SO}_{2}$ derivative treatment could decrease serum-induced VSMC proliferation in a specific time course ranging from 0 to $72 \mathrm{~h}$ (Figure 1b).

Cell cycle analysis demonstrated that VSMCs in a quiescent state tended to stay in the G0/G1 phase (control group compared with fetal bovine serum (FBS) group, $P<0.01$ ); while compared with the FBS group, VSMCs in the $\mathrm{SO}_{2}$-treated groups tended to be in the $\mathrm{G} 0 / \mathrm{G} 1$ phase accompanied with lowered proportions of cells in the G2/M and $\mathrm{S}$ phase (Figure 1c). Hence, $\mathrm{SO}_{2}$ prevented cell cycle progression from the $\mathrm{G} 1$ to the $\mathrm{S}$ phase in serum-induced VSMCs.

The incorporation of bromodeoxyuridine (BrdU) was markedly higher in the serum-stimulated group than that in the quiescent cells $(P<0.01)$. Treatment with $\mathrm{SO}_{2}$ derivatives could significantly reduce incorporation of BrdU, namely the DNA synthesis, by $23.7 \%, 24.5 \%, 28.1 \%$ and $33.8 \%$ at $5,10,15$ and $20 \mu \mathrm{mol} / \mathrm{l}$, respectively (all $P<0.01$; Figure 1d).

Both annexin $\mathrm{V}$-propidium iodide (PI) staining and cell cycle analysis demonstrated that $\mathrm{SO}_{2}$ derivatives at concentrations of $0-100 \mu \mathrm{mol} / \mathrm{l}$ had no effect on apoptosis in the serumstimulated VSMC proliferation model (Figures 1e and f).
$\mathrm{SO}_{2}$ overexpression suppressed serum-induced VSMC proliferation. $\mathrm{SO}_{2}$ could be produced endogenously from sulfur-containing amino-acid L-cysteine in mammals through transamination by aspartate aminotransferase (AAT). To further verify the inhibitory effect of endogenous $\mathrm{SO}_{2}$ on VSMC proliferation, we overexpressed two types of isozymes of AAT (AAT1 and AAT2) in VSMCs. Transfection of VSMCs with AAT1 plasmid or AAT2 plasmid at $2 \mu \mathrm{g}$ markedly increased AAT1 or AAT2 mRNA and protein level compared with vehicle-transfected VSMCs (Figures $2 a-d$ ). Therefore, we used $2 \mu \mathrm{g}$ in subsequent studies. Western blot analysis revealed that either AAT1 or AAT2 overexpression inhibited serum-induced proliferating cell nuclear antigen (PCNA) protein expression in VSMCs (Figure 2e). Similarly, overexpression of AAT1 or AAT2 significantly reduced incorporation of BrdU in serum-treated VSMCs (Figure 2f). Thus, both exogenous- and endogenous-derived $\mathrm{SO}_{2}$ suppressed serum-induced VSMC proliferation.

$\mathrm{SO}_{2}$ deficiency aggravated serum-stimulated VSMC proliferation. To further investigate the potential role of endogenous $\mathrm{SO}_{2}$ in VSMC proliferation, we knocked down AAT1 or AAT2 by shRNA. Specific knockdown of AAT1 or AAT2 was verified by both the mRNA and protein levels (Figures 3a-d). CCK-8 assay showed that either AAT1 or AAT2 silencing significantly exacerbated serum-induced VSMC proliferation (Figure 3e). Consistently, serumenhanced protein expression of PCNA was aggravated in VSMCs transfected with AAT1 or AAT2 shRNA, as well as the incorporation of BrdU (Figures $3 f$ and $g$ ). These data strongly support a significant role of endogenously derived $\mathrm{SO}_{2}$ in the regulation of VSMC proliferation.

Erk/MAPK pathway was involved in the inhibition of PDGF-BB-induced VSMC proliferation by $\mathrm{SO}_{2}$ derivatives. Another part of the BrdU incorporation assay demonstrated that pretreatment with $\mathrm{SO}_{2}$ derivatives at $15 \mu \mathrm{mol} / /$ in $30 \mathrm{~min}$ could markedly lessen DNA synthesis in PDGF-BB-treated VSMCs within $24 \mathrm{~h}(P<0.01$; Figures $4 \mathrm{a}$ and b). Cyclin D1 protein level in VSMCs was elevated within $24 \mathrm{~h}$ after stimulation with PDGF-BB at $50 \mathrm{ng} / \mathrm{ml}(P<0.01)$, whereas pretreatment with $\mathrm{SO}_{2}$ derivatives at $15 \mu \mathrm{mol} / \mathrm{l}$ suppressed PDGF-BB-induced cyclin D1 protein expression $(P<0.01$; Figure $4 \mathrm{C}$ ). The inhibitory effect of $\mathrm{SO}_{2}$ derivatives on cyclin D1 was consistent with the reduced S-phase progression. To further confirm the effect of $\mathrm{SO}_{2}$ on cyclin D1 expression, we overexpressed or knocked down $\mathrm{SO}_{2}$ synthase AAT1 or AAT2 and tested the level of cyclin D1 in VSMCs. As expected, AAT1 or AAT2 overexpression remarkably decreased PDGF-BB-enhanced cyclin D1 expression, whereas AAT1 or AAT2 silencing aggravated PDGF-BBinduced cyclin D1 level (Figures 4d and e).

To determine the signal-transduction basis of cell cycle arrest induced by $\mathrm{SO}_{2}$, we evaluated the activity of Erk/MAPK pathway with the same stimulation method by PDGF-BB. Compared with control cells, cells treated with PDGF-BB displayed a significant increase in Erk1/2, MAPK kinase 1/2 (MEK1/2) and c-Raf activities (all $P<0.01$ ), but not in protein expression of these three signaling molecules (Figures $4 \mathrm{f}-\mathrm{k}$ ). In contrast, $\mathrm{SO}_{2}$ could dephosphorylate the active sites of 
a

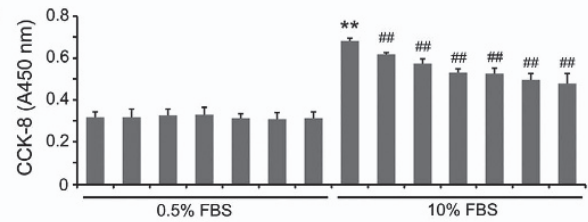

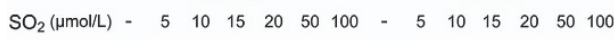

c

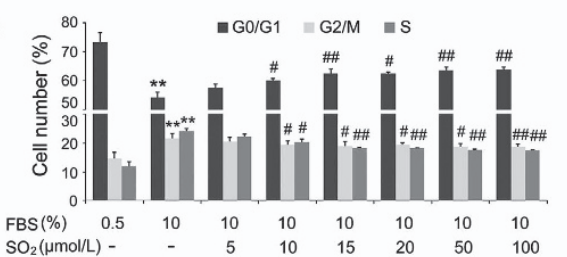

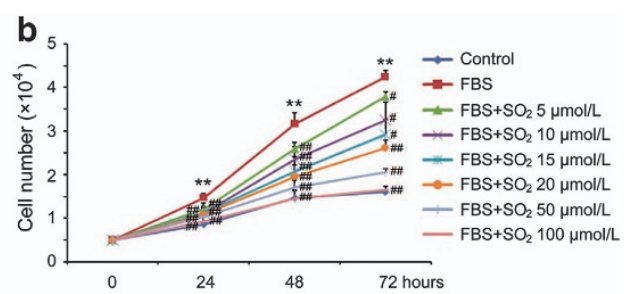

d

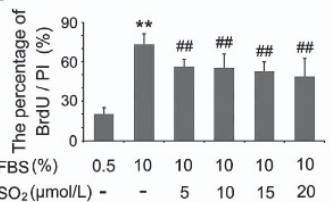

e

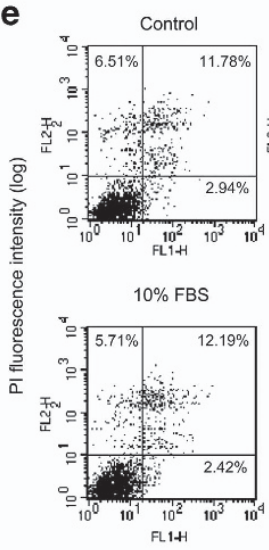

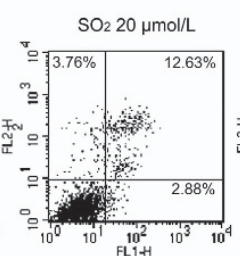
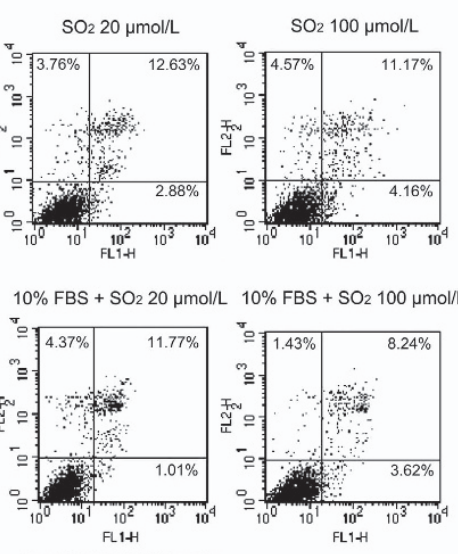

Annexin V-FITC intensity

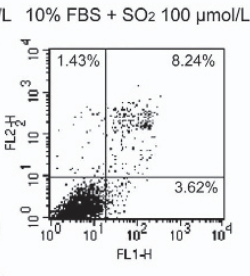

f

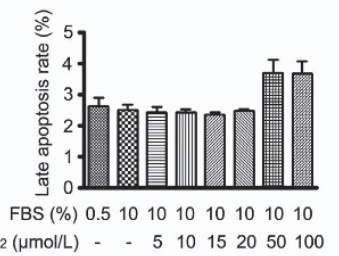

Figure 1 Effects of $\mathrm{SO}_{2}$ derivatives on VSMC viability and serum-induced proliferation. (a) Cell Counting Kit-8 (CCK-8) assay evaluated the viability and serum-stimulated proliferation of VSMCs with $\mathrm{SO}_{2}$ derivatives at $5,10,15,20,50$ and $100 \mu \mathrm{mol} / \mathrm{l}$ for $24 \mathrm{~h}$. Cells were starved in low-serum medium for $24 \mathrm{~h}$, and then treated with or without $\mathrm{FBS}$, as well as with the indicated doses of $\mathrm{SO}_{2}$ derivatives for $24 \mathrm{~h}$. ${ }^{*} P<0.01$ compared with the control group and ${ }^{\# \#} P<0.01$ compared with the FBS group $(n=6$, each containing triplicate). (b) Cell number counting for growth curve analyzed VSMC proliferation in the specific time course. Cells were starved for $24 \mathrm{~h}$ and then treated as shown in the figure. ${ }^{*} P<0.01$ compared with the control group, and ${ }^{\#} P<0.05$ and ${ }^{\# \#} P<0.01$ compared with the FBS group ( $n=4$, each containing triplicate). (c) Effects of $\mathrm{SO}_{2}$ derivatives on cell cycle progression were analyzed by flow cytometry. Cells were starved for $24 \mathrm{~h}$ and then treated with or without FBS, as well as with the indicated doses of $\mathrm{SO}_{2}$ derivatives for $24 \mathrm{~h}$. ${ }^{* \star} P<0.01$ compared with the control group, and ${ }^{\#} P<0.05$ and ${ }^{\# \#} P<0.01$ compared with the FBS group ( $n=3$, each containing triplicate). (d) Inhibitory effects of $\mathrm{SO}_{2}$ derivatives on DNA synthesis in VSMCs. Cells in coverslips were starved for $24 \mathrm{~h}$ and then treated, as shown in the figure, for $24 \mathrm{~h}$ for immunofluorescence assay of BrdU incorporation. Results are expressed as percentages of BrdU-labelled cells to the total amount of cells. ${ }^{* \star} P<0.01$ compared with the control group and ${ }^{\# \#} P<0.01$ compared with the FBS group ( $n=5$, each containing triplicate). (e and f) In vitro assessment of apoptosis in VSMCs. Flow cytometry analysis via annexin V-FITC/PI staining was used to observe the induction of apoptosis. Cells in the lower right quadrant indicated annexin-positive, early apoptosis cells. The cells in the upper right quadrant indicated annexin-positive/PI-positive, late apoptotic cells (e). Cell cycle phase M1 ( $<2 \mathrm{~N}$, late apoptosis) was determined by PI staining and subsequent flow cytometry analysis (f). Data are presented as mean \pm S.D. of at three to six independent experiments, each in triplicate

Erk1/2 on Thr202/Tyr204, MEK1/2 on Ser217/221 and c-Raf on Ser338 $(P<0.05, P<0.05$ and $P<0.01$, respectively; Figures $4 \mathrm{f}-\mathrm{k})$. These findings implied that the inhibitory effect of $\mathrm{SO}_{2}$ on VSMC proliferation might be mediated by the Erk/MAPK pathway.

$\mathrm{SO}_{2}$ derivatives could not directly influence the activation of Erk1/2, MEK1/2 and c-Raf. We constructed three types of constitutively active (CA) MEK plasmids, breaking the stabilization of the inactive state of MEK. HEK293 cells exposed to CA-MEK plasmid transfection showed a sustained increased phosphorylation of Erk1/2 compared with that in the MEK wild-type group (all $P<0.05$; Figure 5a). However, the pretreatment with $\mathrm{SO}_{2}$ derivatives could not suppress the phosphorylation of Erk1/2 activated by mutant CA-MEK (Figure 5a), indicating that $\mathrm{SO}_{2}$ derivatives were unable to inhibit the phosphorylation of Erk1/2 molecule directly. We inferred from the result that the inhibitory effect of $\mathrm{SO}_{2}$ might result from upstream Erk1/2 molecules.

c-Raf kinase activity assay is based on the biochemical reaction using inactive recombinant MEK1 as a c-Raf substrate. After extracting cytoplasmic protein from normal cultured VSMCs, we added the total proteins (containing active c-Raf) and $\mathrm{SO}_{2}$ derivatives at 5, 10, 15 and $20 \mu \mathrm{mol} / \mathrm{l}$ into the enzymatic reaction system. We found that there was no difference between the control group and the $\mathrm{SO}_{2}$ derivative-treated groups (Figure $5 \mathrm{~b}$ ). To assess the effect of $\mathrm{SO}_{2}$ on specific c-Raf kinase activity, we used the recombinant c-Raf protein purified from human HEK293 cells instead of extracting cytoplasmic protein. Similarly, the results showed that $\mathrm{SO}_{2}$ did not change the phosphorylation of recombinant MEK1 (Figure 5c), which suggested that $\mathrm{SO}_{2}$ 
a

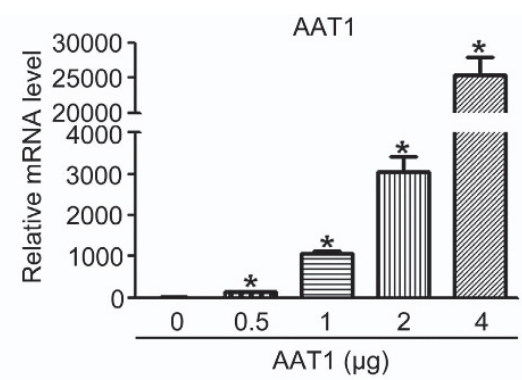

c

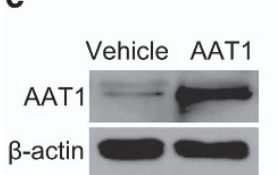

e

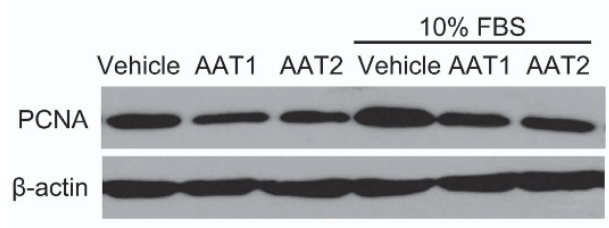

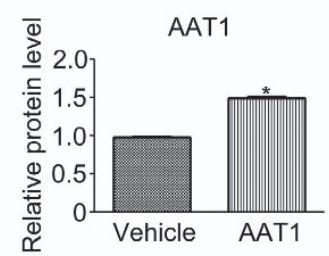

b

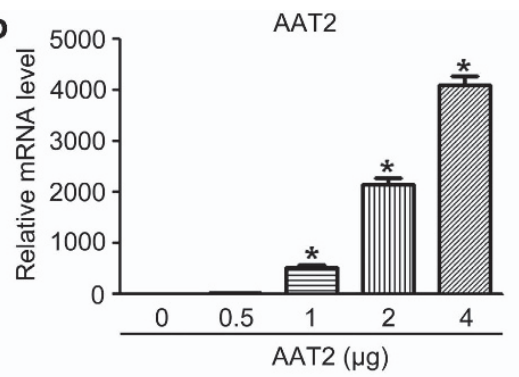

d
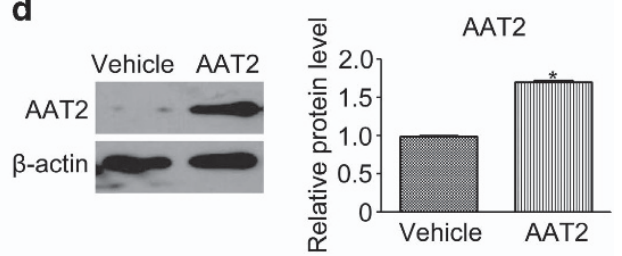

PCNA

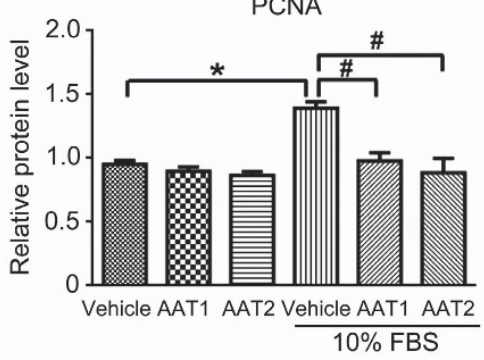

f

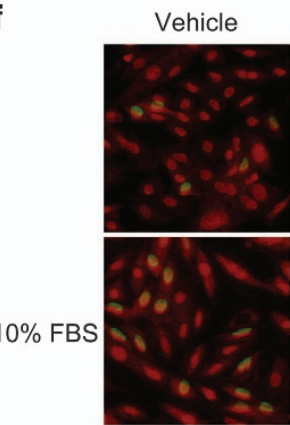


a

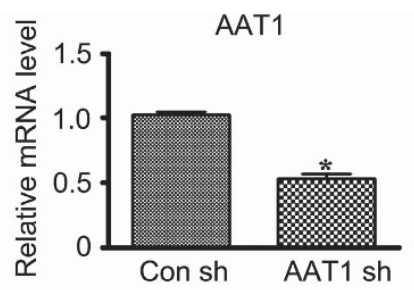

C
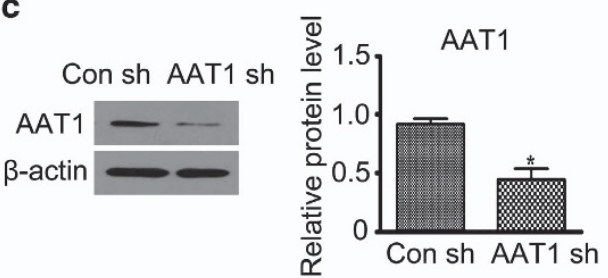

e

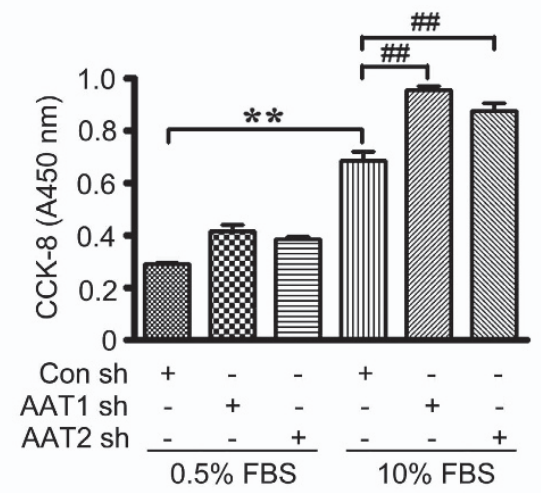

g

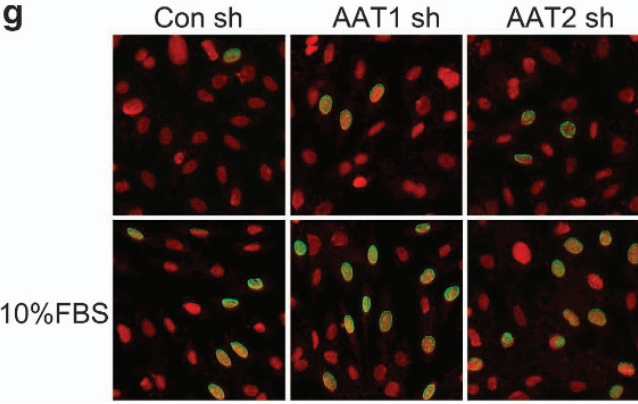

b

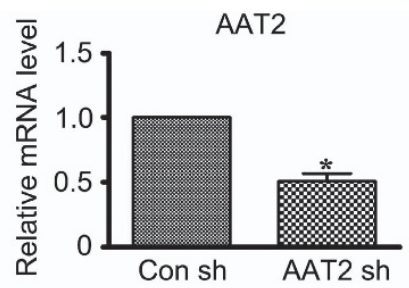

d

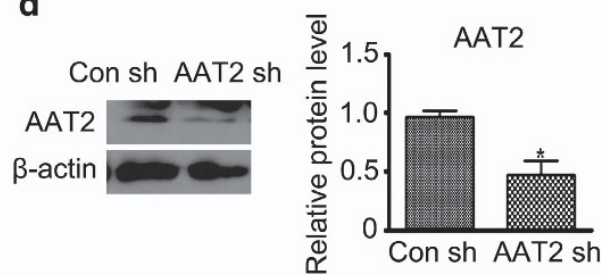

f

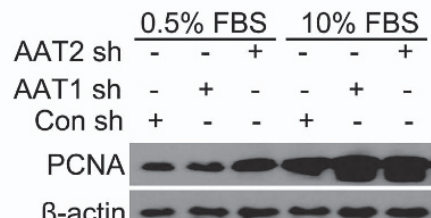

$-\infty-2$
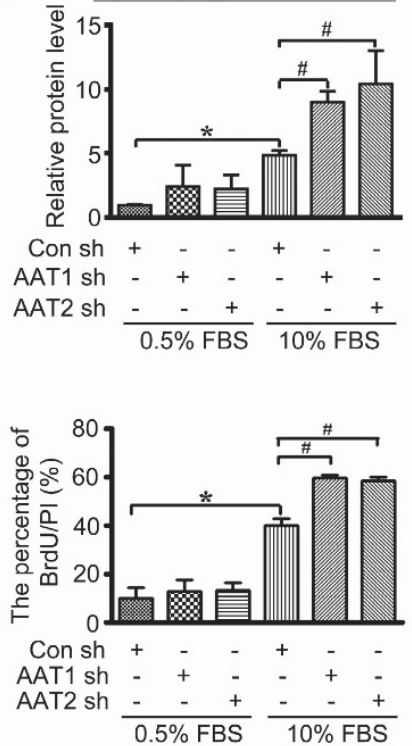

Figure $3 \mathrm{SO}_{2}$ knockdown exacerbated serum-stimulated VSMC proliferation. (a and $\left.\mathbf{b}\right)$ mRNA levels of AAT1 (a) and AAT2 (b) were quantified by real-time PCR. VSMCs were transfected with Con, AAT1 or AAT2 short hairpin RNA (shRNA) for $24 \mathrm{~h} .{ }^{*} P<0.05$. (c and d) Protein expression of AAT1 (c) and AAT2 (d) in VSMCs transfected with Con, AAT1 or AAT2 shRNA for $48 \mathrm{~h} .{ }^{*} P<0.05$. (e) Cell Counting Kit-8 (CCK-8) assay evaluated serum-stimulated proliferation of VSMCs transfected with Con, AAT1 or AAT2 shRNA for $48 \mathrm{~h} .{ }^{* *} P<0.01$ compared with the control shRNA group and ${ }^{\# \#} P<0.01$ compared with the FBS group. (f) Representative western blot and quantification of PCNA in VSMCs transfected with Con, AAT1 or AAT2 shRNA before serum treatment. ${ }^{*} P<0.05$ compared with the control shRNA group and ${ }^{\#} P<0.05$ compared with the serum group. (g) Immunofluorescence assay of BrdU incorporation. VSMCs in coverslips were transfected with Con, AAT1 or AAT2 shRNA before serum treatment. Green fluorescence stands for cells with DNA synthesis, whereas red fluorescence stands for total cells. ${ }^{*} P<0.05$ compared with the control shRNA group and ${ }^{\#} P<0.05$ compared with the serum group. Data are means \pm S.D. of at least three independent experiments, each in triplicate

contrast, $\mathrm{SO}_{2}$ derivative-pretreated cells displayed an increasing phosphorylation of $\mathrm{c}$-Raf on Ser259 compared with PDGF-BB-treated cells $(P<0.05)$, and meanwhile, there was no difference in Ser43 phosphorylation between the two groups (Figure 6a). Furthermore, compared with resting cells, the cells treated only by $\mathrm{SO}_{2}$ derivatives for $30 \mathrm{~min}$ showed a high phosphorylating level both in Ser259 and Ser43 sites (both $P<0.05$; Figure 6 a). The findings illustrated that even though $\mathrm{SO}_{2}$ derivatives could stimulate c-Raf phosphorylation on both Ser259 and Ser43 sites, as for PDGF-BB treatment, the Ser259 site of c-Raf had an important role in the signaling crosstalk mechanism in which $\mathrm{SO}_{2}$ derivative-induced suppression of the Erk/MAPK pathway was involved.

Subsequently, we used Forskolin, an AC activator that could increase the intracellular cAMP concentration, and 


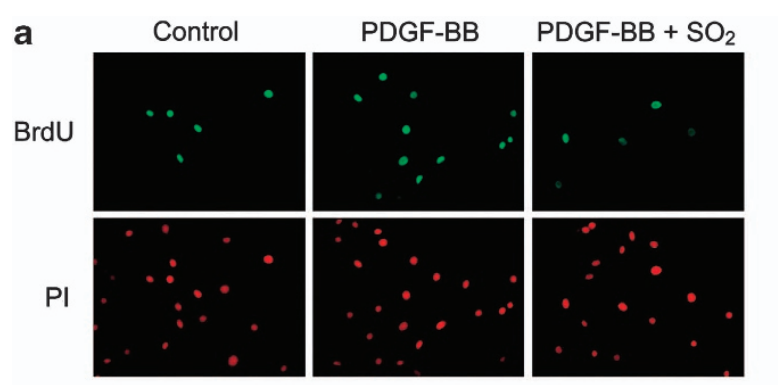

d
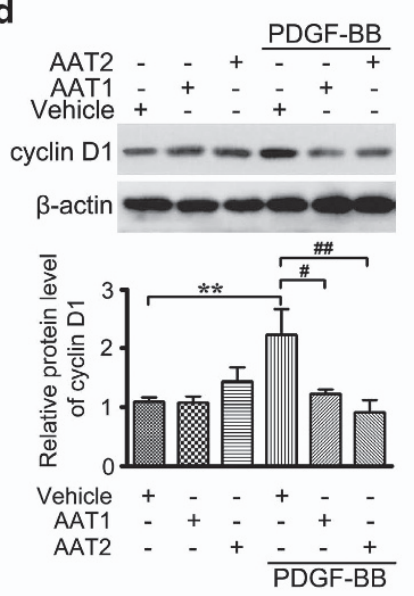

h

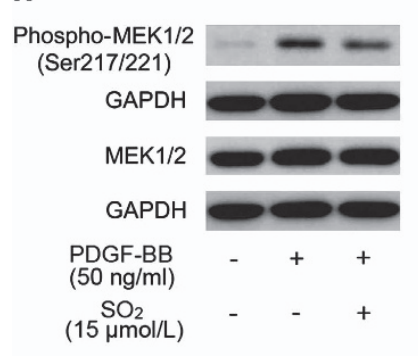

e

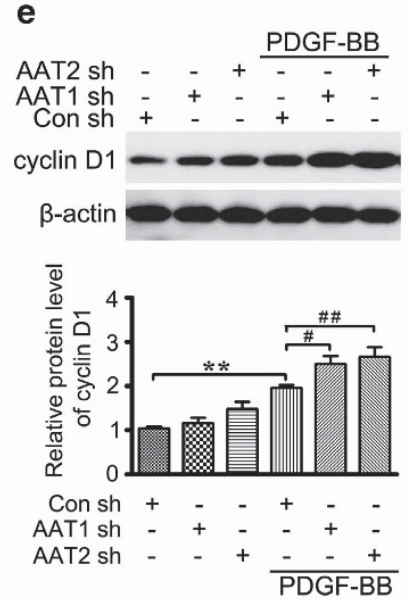

b

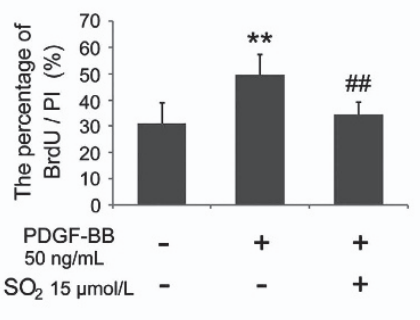

C cyclin D1

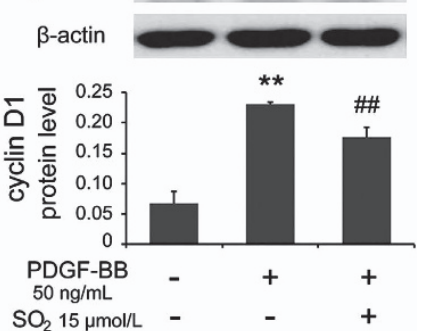

f $\mathbf{g}$

Phospho-Erk1/2 (Thr202/Tyr204) GAPDH

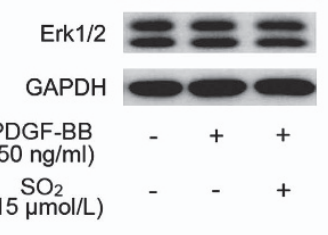

g

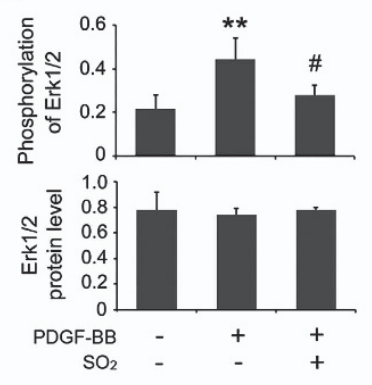

Figure $4 \mathrm{SO}_{2}$ derivatives suppressed VSMCs proliferation by inhibiting Erk/MAPK pathway. (a and $\mathbf{b}$ ) Inhibitory effects of $\mathrm{SO}_{2}$ derivatives on DNA synthesis in PDGF-BBinduced VSMCs. Cells in coverslips were starved for $24 \mathrm{~h}$ and then pretreated with or without $\mathrm{Na}_{2} \mathrm{SO}_{3} / \mathrm{NaHSO}_{3}$ at $15 \mu \mathrm{mol} / \mathrm{l}$ for $30 \mathrm{~min}$, as well as with PDGF-BB at $50 \mathrm{ng} / \mathrm{ml}$ treatment for $24 \mathrm{~h}$ for immunofluorescence assay of BrdU incorporation. Green fluorescence stands for cells with DNA synthesis, whereas red fluorescence stands for total cells. ${ }^{\star *} P<0.01$ compared with the control group and ${ }^{\# \#} P<0.01$ compared with the PDGF-BB group ( $n=5$, each containing triplicate). (c) Roles of $\mathrm{SO}_{2}$ derivatives in cyclin D1 protein expression in PDGF-BB-stimulated VSMCs. Cells, starved for $24 \mathrm{~h}$, were pretreated with or without $\mathrm{Na}_{2} \mathrm{SO}_{3} / \mathrm{NaHSO}_{3}$ at $15 \mu$ mol/l for 30 min and treated with PDGF-BB at $50 \mathrm{ng} / \mathrm{ml}$ for $24 \mathrm{~h}$. ${ }^{* *} P<0.01$ compared with the control group, and ${ }^{\#} P<0.05$ and ${ }^{\# \#} P<0.01$ compared with the PDGF-BB group ( $n=3$, each containing triplicate). (d and e) Representative western blot and quantification of cyclin D1 in VSMCs transfected with vehicle, AAT1 or AAT2 (d) or Con, AAT1 or AAT2 shRNA (e) before PDGF-BB treatment. ${ }^{* *} P<0.01$ compared with the control group, and ${ }^{\#} P<0.05$ and ${ }^{\# \#} P<0.01$ compared with the serum group. (f-k) Roles of $S \mathrm{O}_{2}$ derivatives in the phosphorylations and protein expressions of Erk/MAPK pathway in $\mathrm{PDGF}-\mathrm{BB}$-stimulated $\mathrm{VSMCs}$. Cells, starved for $24 \mathrm{~h}$, were pretreated with or without $\mathrm{Na}_{2} \mathrm{SO}_{3} / \mathrm{NaHSO}_{3}$ at $15 \mu \mathrm{mol} / /$ for $30 \mathrm{~min}$ and treated with PDGF-BB at $50 \mathrm{ng} / \mathrm{ml}$ for $24 \mathrm{~h}$. Total cellular proteins were extracted for western blotting analysis. ${ }^{\star \star} P<0.01 \mathrm{compared}$ with the control group, and ${ }^{\#} P<0.05$ and ${ }^{\# \#} P<0.01$ compared with the PDGF-BB group ( $n=3$, each containing triplicate). Data are presented as mean \pm S.D. of three to five independent experiments, each in triplicate. GAPDH, glyceraldehyde 3-phosphate dehydrogenase

$\mathrm{H}-89$, a selective inhibitor of PKA, to determine the role of $\mathrm{SO}_{2}$ derivatives in the CAMP/PKA pathway. As the key of crosstalk between CAMP/PKA and Erk/MAPK pathways, the two sites, Ser259 and Ser43 of c-Raf as the targets of PKA signaling, showed high phosphorylations in both $\mathrm{SO}_{2}$ derivative- and Forskolin-treated groups (all $P<0.05$; Figure 6d), accompanied with the same changing tendency in the activation of the PKA signal (both $P<0.01$; Figure $6 \mathrm{~d}$ ). $\mathrm{SO}_{2}$ could not release the repressed activity of PKA pretreated with $\mathrm{H}-89$ in advance, indicating that the stimulation step of cAMP/PKA pathway by $\mathrm{SO}_{2}$ derivatives might occur in the signaling pathway upstream of the PKA molecule. Fortunately, by examining the cAMP concentrations by the same interference method as above, we discovered that $\mathrm{SO}_{2}$ derivatives could elevate cAMP concentration no matter whether the cells were pretreated with $\mathrm{H}-89$ or not (both $P<0.01$; Figures $7 \mathrm{a}$ and b).

To complement this study, we also evaluated the proliferative status influenced by $\mathrm{SO}_{2}$ after interfering with both 

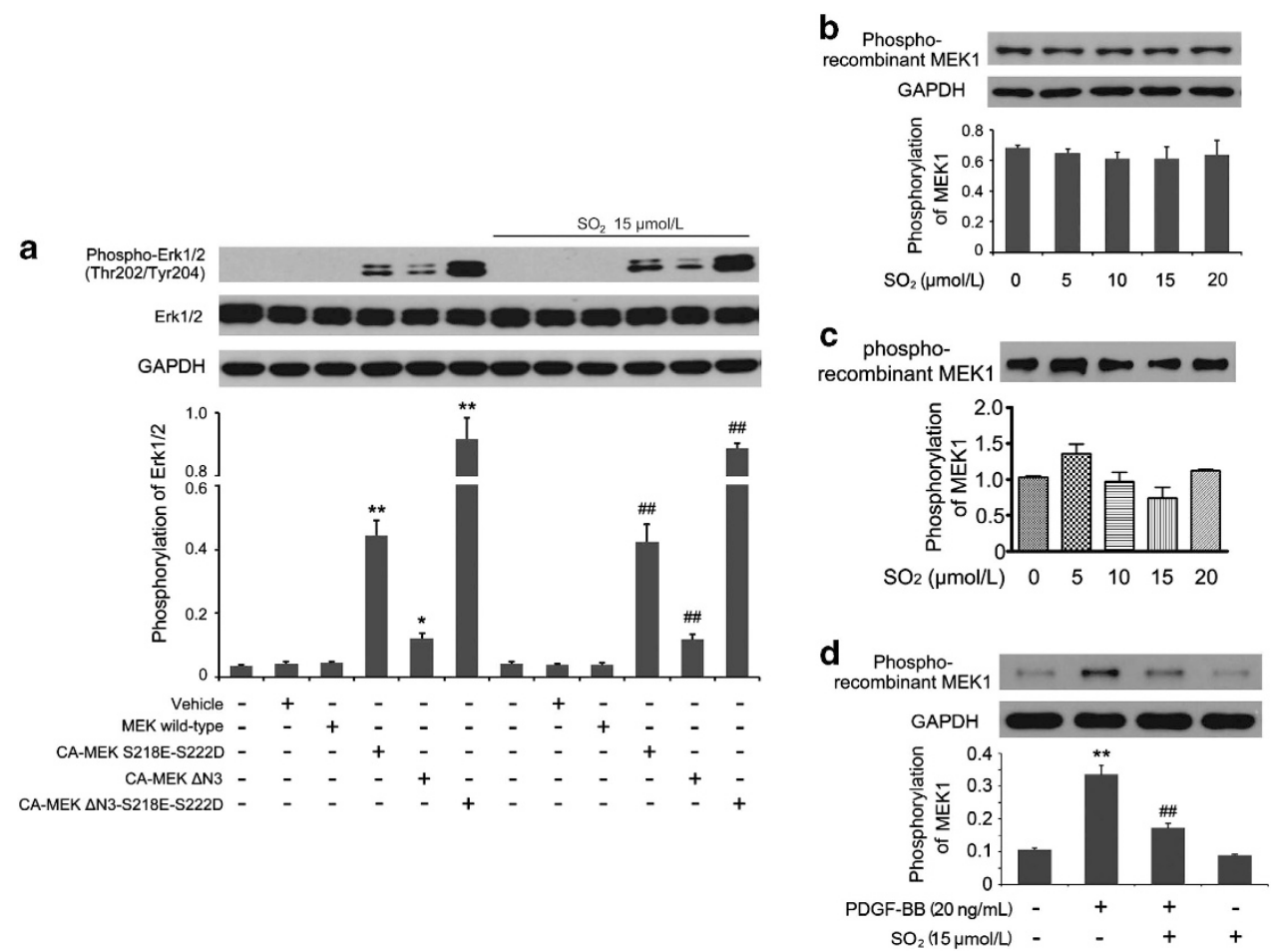

Figure $5 \quad \mathrm{SO}_{2}$ derivatives did not inhibit the activation of Erk1/2, MEK1/2 and c-Raf molecules directly. (a) After transfected with different plasmids as described in the figure, HEK293 cells in experimental groups were treated with $\mathrm{Na}_{2} \mathrm{SO}_{3} / \mathrm{NaHSO}_{3}$ at $15 \mu \mathrm{mol} / \mathrm{l}$ for $24 \mathrm{~h}$. The phosphorylation of Erk1/2 was assessed by western blotting. ${ }^{*} P<0.05$ and ${ }^{* *} P<0.01$ compared with the MEK wild-type group and ${ }^{\# \#} P<0.01$ compared with the MEK wild-type $+\mathrm{Na}_{2} \mathrm{SO}_{3} / \mathrm{NaHSO}_{3} \mathrm{group}(n=3$, each containing triplicate). ( $\mathbf{b}$ and $\mathbf{c}$ ) Different concentrations of $\mathrm{Na}_{2} \mathrm{SO}_{3} / \mathrm{NaHSO}_{3}$ were added into protein extraction of normal cultured cells (b) or purified c-Raf protein (c) before the beginning of the $c$-Raf enzymatic reaction. $c$-Raf kinase activity was expressed as the phosphorylation of recombinant inactive MEK 1 by western blotting analysis $(n=3$, each containing triplicate). (d) Cells, starved for $24 \mathrm{~h}$, were pretreated with or without $\mathrm{Na}_{2} \mathrm{SO}_{3} / \mathrm{NaHSO}_{3}$ at $15 \mu \mathrm{mol} / / \mathrm{for} 30 \mathrm{~min}$ and treated with or without PDGF-BB at $20 \mathrm{ng} / \mathrm{ml}$ for $30 \mathrm{~min}$. Cellular proteins were extracted for c-Raf kinase activity assay. Results were expressed as the phosphorylation of recombinant inactive MEK1 by western blotting analysis. ${ }^{*} P<0.01$ compared with the control group and ${ }^{\# \#} P<0.01$ compared with the PDGF-BB group $(n=3$, each containing triplicate). Data are presented as mean \pm S.D. of three independent experiments, each in triplicate. GAPDH, glyceraldehyde 3-phosphate dehydrogenase

cAMP/PKA and Erk/MAPK pathways. The results showed that $\mathrm{SO}_{2}$ could inhibit PDGF-BB-stimulated VSMC proliferation $(P<0.01)$, whereas $\mathrm{H}-89$ reversed the $\mathrm{SO}_{2}$ derivativeinduced suppression of proliferation by repressing PKA activity $(P<0.01$; Figure $7 \mathrm{c})$. According to the above findings, we deduced that $\mathrm{SO}_{2}$ might inhibit VSMC proliferation by stimulating $\mathrm{AC}$ activity.

\section{Discussion}

Along with the recognition of $\mathrm{H}_{2} \mathrm{~S}$ as a gaseous signaling molecule in the cardiovascular system, there has been increasing attention paid to the physiological and pathophysiological functions of $\mathrm{SO}_{2}$, as a novel gasotransmitter in cardiovascular regulation. L-Cysteine is the major precursor of endogenous $\mathrm{SO}_{2}$. It can be metabolized to L-cysteine sulfinate by cysteine dioxygenase (CDO). L-Cysteine sulfinate is then metabolized to $\beta$-sulfinylpyruvate via AAT. ${ }^{20,29} \beta$-Sulfinylpyruvate degrades rapidly, producing pyruvate and $\mathrm{SO}_{2}{ }^{20,29}$ Some of the endogenous $\mathrm{SO}_{2}$ is hydrated to sulfite, whereas the other part stays in the gaseous form. ${ }^{30,31}$ Our previous study demonstrated CDO and AAT expression in several tissues and organs in mammals accompanied with the generation of $\mathrm{SO}_{2}{ }^{32}$ The plasma concentration of endogenous $\mathrm{SO}_{2}$ in Wistar rats is $15.44 \pm 1.68 \mu \mathrm{mol} / \mathrm{l}$, evaluated by high-performance liquid chromatography with fluorescence detection. ${ }^{33}$ The studies on hypoxic pulmonary hypertensive rats showed that $\mathrm{SO}_{2}$ might be involved in the pathogenesis. ${ }^{34}$ However, whether does $\mathrm{SO}_{2}$ regulate VSMC proliferation? If it does, what are the possible regulatory mechanisms? All the questions have no answer.

In their resting state, VSMCs in adults maintain their contractile phenotype. When vascular injury occurs, VSMCs can undergo phenotypic switching into the synthetic phenotype to repair the vasculature by their remarkable plasticity, representing migration and proliferation. ${ }^{1}$ Although this phenotypic modulation of VSMCs might derive from evolutionary selfrepair ability, the consequences are mostly unsatisfying, resulting in conditions such as restenosis. ${ }^{35}$ In addition, several studies have found that this part of phenotypic switching VSMCs shows heterogeneity and might be from a monoclonal origin, similar to that of tumorigenesis. ${ }^{36-39}$ Therefore, if we could find a regulating procedure in VSMC proliferation, it will help preventing this excessive self-repairing.

The present research demonstrated that $\mathrm{SO}_{2}$ could bring about cell cycle arrest in both FBS- and PDGF-BB-treated VSMCs by downregulating DNA synthesis to delay the proliferation process. After recognizing PDGF receptors, PDGFs combine with their specific RTKs and activate ras to initiate MAPK signaling. ${ }^{40}$ As shown in this study, $\mathrm{SO}_{2}$ led to 


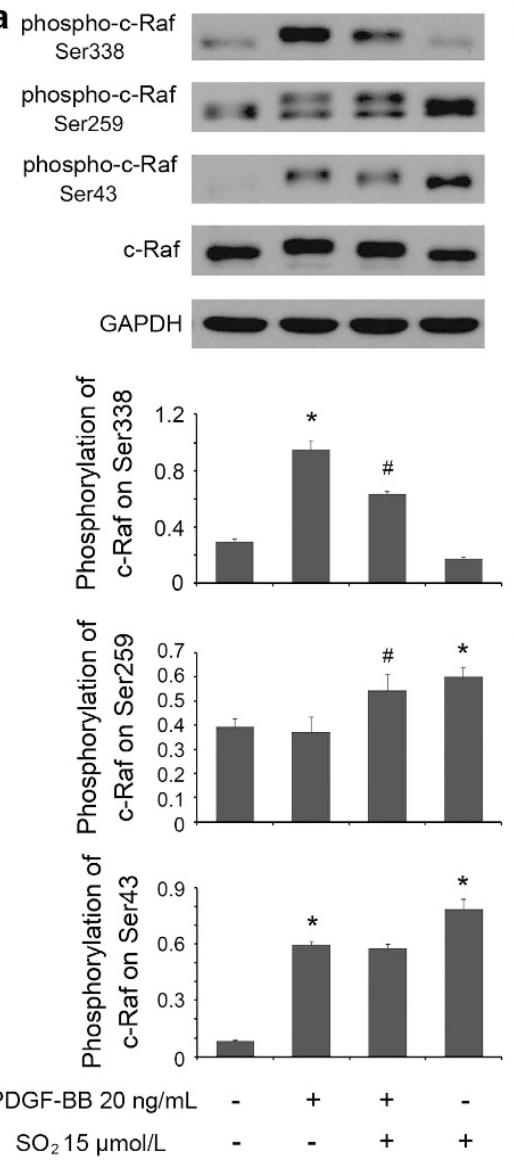

b
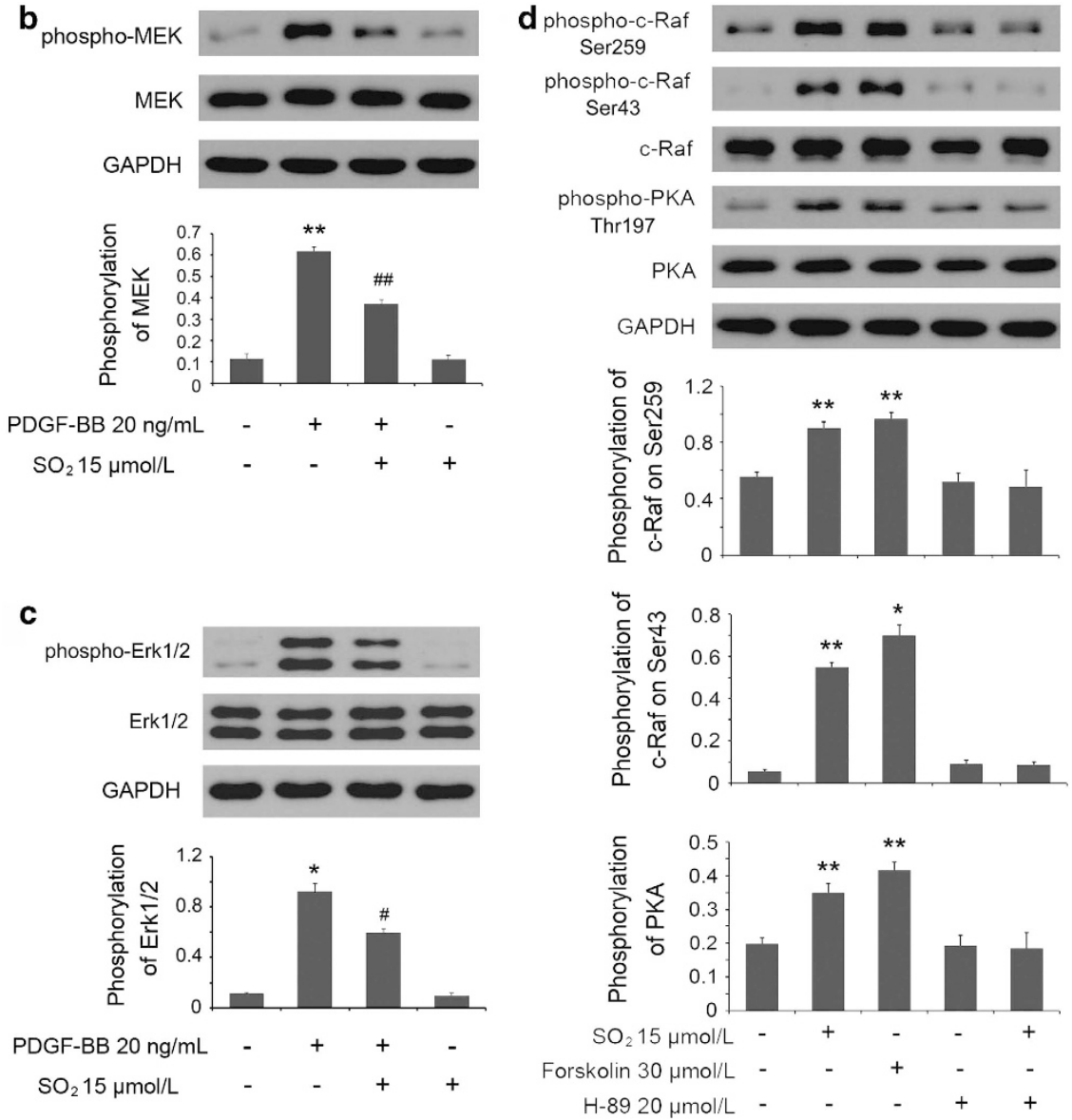

Figure 6 The crosstalk between CAMP/PKA and Erk/MAPK pathways mediated $\mathrm{SO}_{2}$-suppressed Erk/MAPK signaling. (a-c) Cells, starved for $24 \mathrm{~h}$, were pretreated with or without $\mathrm{Na}_{2} \mathrm{SO}_{3} / \mathrm{NaHSO}_{3}$ at $15 \mu \mathrm{mol} / /$ for $30 \mathrm{~min}$ and treated with or without PDGF-BB at $20 \mathrm{ng} / \mathrm{ml}$ for $30 \mathrm{~min}$. Cellular proteins were extracted for western blotting to determine the phosphorylations of Erk1/2, MEK1/2 and c-Raf on Ser338, Ser259 and Ser43. ${ }^{*} P<0.05$ and ${ }^{* \star} P<0.01$ compared with the control group, and ${ }^{\#} P<0.05$ and ${ }^{\#} P<0.01$ compared with the PDGF-BB group ( $n=3$, each containing triplicate). (d) Cells, starved for $24 \mathrm{~h}$, were untreated or treated with $\mathrm{Na}_{2} \mathrm{SO}_{3} / \mathrm{NaHSO}_{3}$ at $15 \mu \mathrm{mol} / \mathrm{l}$ for $30 \mathrm{~min}$, or treated with Forskolin at $30 \mu \mathrm{mol} / / \mathrm{l}$ for $30 \mathrm{~min}$, or treated with $\mathrm{H}-89$ at $20 \mu \mathrm{mol} / \mathrm{l}$ for $30 \mathrm{~min}$, or pretreated with $\mathrm{H}-89$ at $20 \mu \mathrm{mol} / /$ for $20 \mathrm{~min}$ and then treated with $\mathrm{Na}_{2} \mathrm{SO}_{3} / \mathrm{NaHSO}_{3}$ at $15 \mu \mathrm{mol} / /$ for $30 \mathrm{~min}$. The phosphorylations of c-Raf on Ser259 and Ser43 and PKA on Thr197 were estimated by western blotting analysis. ${ }^{*} P<0.05$ and ${ }^{* \star} P<0.01$ compared with the control group ( $n=3$, each containing triplicate). Data are presented as mean \pm S.D. of three independent experiments, each in triplicate. GAPDH, glyceraldehyde 3-phosphate dehydrogenase
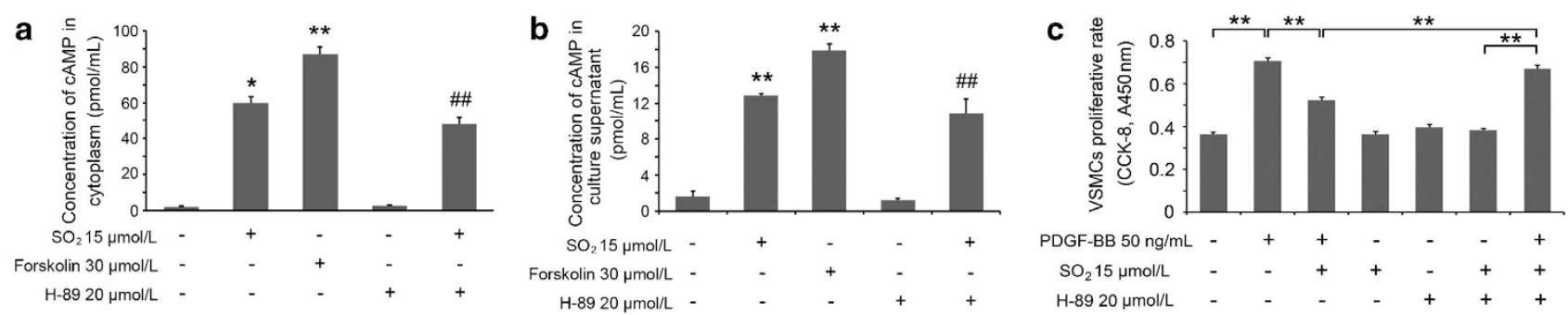

Figure 7 cAMP elevation in VSMCs by $\mathrm{SO}_{2}$ derivatives may mediate the inhibition of proliferation. (a and $\left.\mathbf{b}\right)$ Cells, starved for $24 \mathrm{~h}$, were untreated or treated with $\mathrm{Na}_{2} \mathrm{SO}_{3} /$ $\mathrm{NaHSO}_{3}$ at $15 \mu \mathrm{mol} / / \mathrm{f}$ for $30 \mathrm{~min}$, or treated with Forskolin at $30 \mu \mathrm{mol} / /$ for $30 \mathrm{~min}$, or treated with $\mathrm{H}-89$ at $20 \mu \mathrm{mol} / /$ for $30 \mathrm{~min}$, or pretreated with $\mathrm{H}-89$ at $20 \mu \mathrm{mol} / / \mathrm{for} 20 \mathrm{~min}$ and then treated with $\mathrm{Na}_{2} \mathrm{SO}_{3} / \mathrm{NaHSO}_{3}$ at $15 \mu \mathrm{mol} / /$ for $30 \mathrm{~min}$. Samples of cellular extractions and culture supernatants were used for the measurement of cAMP concentrations. ${ }^{*} P<0.05$ and ${ }^{* *} P<0.01$ compared with the control group, and ${ }^{\# \#} P<0.01$ compared with the $\mathrm{H}-89$ group ( $n=3$, each containing triplicate). (c) Cells, starved for $24 \mathrm{~h}$, and treated sequentially with $\mathrm{H}-89$ at $20 \mu \mathrm{mol} / /, \mathrm{Na}_{2} \mathrm{SO}_{3} / \mathrm{NaHSO}_{3}$ at $15 \mu \mathrm{mol} / \mathrm{l}$ and PDGF-BB at $50 \mathrm{ng} / \mathrm{ml}$. After $24 \mathrm{~h}$, the proliferative rate was evaluated by Cell Counting Kit-8 (CCK-8) assay. ${ }^{\star *} P<0.01(n=6$, each containing triplicate). Data are presented as mean \pm S.D. of three to six independent experiments, each in triplicate

decreasing DNA synthesis and cyclin D1 protein expression in PDGF-BB-treated VSMCs simultaneously with the inactivation of Erk/MAPK pathway, implying that the Erk/MAPK cascade mediated the suppressing effect of the proliferation.
As the signal transduction of Erk/MAPK pathway is a series of kinase reactions in sequence, we need to clarify if the inactive Erk1/2, MEK1/2 and c-Raf are the result of separate targeting interferences of $\mathrm{SO}_{2}$ or from the inhibition of upstream signal 
transmission. Nevertheless, $\mathrm{SO}_{2}$ could not impede activation of Erk $1 / 2$ by CA-MEK, or retard the enzymatic reaction catalyzed by $\mathrm{c}$-Raf to produce activate MEK, both of which support that the negative effects of $\mathrm{SO}_{2}$ on the Erk/MAPK pathway were mediated by upstream signals.

The activation of c-Raf needs the cooperation of several kinases, phosphatases and scaffolding proteins, which compose a complex surrounding c-Raf. ${ }^{41,42}$ As the center subunit, the phosphorylations of different sites on c-Raf decide the conformation of the complex, leading to an 'active' or 'inactive' structure. The phosphorylations of the four sites, Ser338, Tyr341, Thr491 and Ser494, are essential for c-Raf activation. ${ }^{43}$ However, in VSMCs, the cAMP/PKA pathway can target $c$-Raf by blocking its activation. ${ }^{23}$ PKA could stimulate Ser621, Ser43, Ser233 and Ser259 on c-Raf separately to inhibit c-Raf activation. ${ }^{27,43}$ The phosphorylation of Ser43 on c-Raf could directly hinder the 'active' conformation of the complex, ${ }^{44}$ whereas Ser233 and Ser259 manage to recruit 14-3-3 proteins to the $\mathrm{N}$ terminus of $\mathrm{c}-\mathrm{R}$ af to disturb ras binding. ${ }^{26,45}$ Our present study considered the Ser43 and Ser259 sites on c-Raf as subjects to seek for the interaction between the two signal pathways. The results showed that in quiescent VSMCs, Ser259 displayed mild phosphorylation, whereas PDGF-BB treatment did not change this status. However, if pretreated with $\mathrm{SO}_{2}$ derivatives, PDGF-BBinduced VSMCs had a further increased quantity of Ser259 phosphorylation, lowered c-Raf kinase activity and increased PKA activation, suggesting that $\mathrm{SO}_{2}$ derivatives might inhibit C-Raf activation by stimulating Ser259 phosphorylation on c-Raf by triggering PKA. Regarding the Ser43 site on c-Raf, we found that it stayed in a dephosphorylated state in resting VSMCs, and meanwhile, both PDGF-BB and $\mathrm{SO}_{2}$ derivative treatment could elevate its phosphorylation level, respectively. The similar phosphorylation of Ser43 on c-Raf between the PDGF-BB group and the PDGF-BB $+\mathrm{SO}_{2}$ derivative group implied that the antagonistic effect of $\mathrm{SO}_{2}$ derivatives on PDGF-BB-stimulated c-Raf was not a result of the phosphorylation of Ser43 in VSMCs.

Until now, the underlying mechanism of the inactivation of c-Raf stimulated by PKA is still completely unrevealed, partly because of the complicated conformation of c-Raf and its scaffold proteins. Therefore, several models exist simultaneously. In resting cells, both Ser259 and Ser261 on c-Raf presented phosphorylation binding with 14-3-3 proteins to maintain the complex in a 'closed' state. ${ }^{26,43}$ Previous research testified that compared with Ser621, Ser259 was more important to modulate c-Raf complex conformation. ${ }^{46}$ The activation of ras could isolate 14-3-3 proteins from the CR2 domain in c-Raf, accompanied with dephosphorylation of Ser259, resulting in c-Raf activation and MEK coupling. ${ }^{46}$ When the PKA signal was agonized by high levels of CAMPphosphorylated Ser43 and Ser233 on c-Raf, 14-3-3 proteins could find another binding site, Ser233, on c-Raf, and eventually c-Raf inactivation occurred. ${ }^{26,47}$ Other research groups discovered that in quiescent cells, merely $30 \%$ of the Ser259 sites on c-Raf showed phosphorylation and were coupled with 14-3-3 proteins, and CAMP could make Ser259 phosphorylation promoted by two- to threefold. ${ }^{47}$ This finding corresponded with our present study in VSMCs. The combination of 14-3-3 proteins and Ser259 could impede

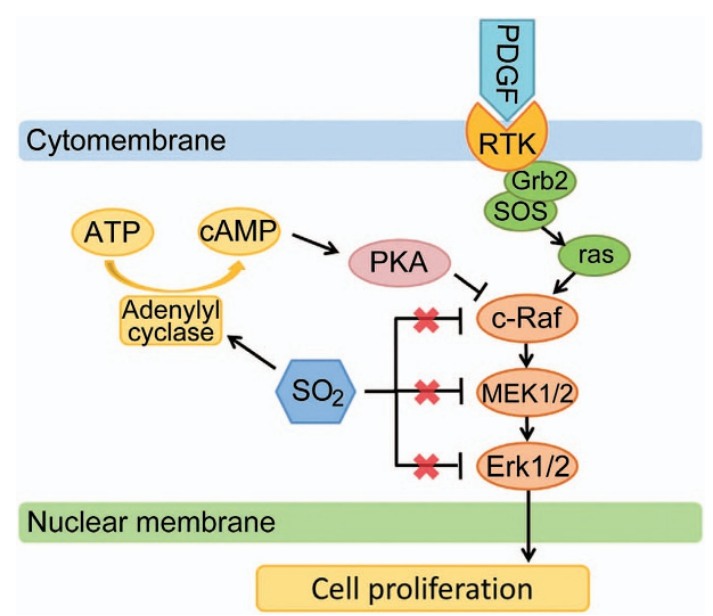

Figure 8 A schematic diagram of the inhibition of proliferation by $\mathrm{SO}_{2}$ and the pathways. PDGF-BB can promote VSMC proliferation by activating Erk/MAPK pathway after combining with its specific RTKs. The increasing CAMP concentration in VSMCs induces PKA activation, which can disturb Erk/MAPK signaling transduction by inhibiting $\mathrm{c}$-Raf activation. $\mathrm{SO}_{2}$ derivatives can suppress the activities of Erk1/2, MEK1/2 and c-Raf, which does not result from separate targeting interferences of $\mathrm{SO}_{2}$ derivatives on the three molecules but from the inhibition of upstream signaling by $\mathrm{SO}_{2}$ derivatives. $\mathrm{SO}_{2}$ derivatives might enhance adenylyl cyclase activity to elevate CAMP production from ATP and then activate PKA signal to block c-Raf activation, which finally contributes to the suppression of PDGF-BB-induced VSMC proliferation by $\mathrm{SO}_{2}$ derivatives

the recruitment of $\mathrm{c}$-Raf to proximal cytomembrane for activation, ${ }^{48,49}$ whereas increasing cAMP could recruit c-Raf with dephosphorylated Ser259 to the cytomembrane area. ${ }^{47}$ Even though there are still controversies about those c-Raf complex models, just as the opposite effects of the cAMP/ PKA pathway on the Erk/MAPK signaling in distinct cell types, ${ }^{43}$ the diversity of c-Raf sites' phosphorylation in quiescent state or induced by PKA might be associated with species or tissue specificity. Therefore, our present study results are interesting, as they demonstrate that in PDGF-BBstimulated rat VSMCs, the phosphorylation on Ser259 of c-Raf induced by $\mathrm{SO}_{2}$-activated PKA might attribute to the inhibition of Erk/MAPK transmission.

For further exploration, we used a PKA inhibitor and an AC agonist to look for the target of $\mathrm{SO}_{2}$ on the cAMP/PKA pathway by analyzing CAMP concentration and PKA activation. The results revealed that $\mathrm{SO}_{2}$ could elevate cAMP production, no matter whether PKA was blocked or not. This implicates that $\mathrm{SO}_{2}$ might enhance AC activity to increase cAMP generation and in this way facilitate the effect of PKA on Ser259 of c-Raf. In addition, according to CCK-8 assay, blocking PKA activity could prevent $\mathrm{SO}_{2}$ from suppressing PDGF-BB-induced VSMC proliferation, meaning that $\mathrm{SO}_{2}$ derivatives might inhibit VSMC proliferation via the interaction between the cAMP/PKA and the Erk/MAPK pathways (Figure 8).

In conclusion, the present study justified the inhibitory effect of $\mathrm{SO}_{2}$ derivatives on rat VSMC proliferation by downregulating the activity of Erk/MAPK pathway. The underlying mechanism might involve elevating cellular cAMP production by $\mathrm{SO}_{2}$ to activate the PKA signal, resulting in phosphorylation on Ser259 of c-Raf to block its activation. Eventually, this will contribute to the suppression of the Erk/MAPK signaling transduction. 


\section{Materials and Methods}

Cell culture. Rat A7r5 VSMCs and HEK293 cells were both obtained from the American Type Culture Collection (Manassas, VA, USA). Cells were cultured in Dulbecco's modified Eagle's medium (DMEM) containing 10\% FBS, $2 \mathrm{mmol} / \mathrm{l}$ glutamine and $20 \mathrm{mmol} / / \mathrm{HEPES}(\mathrm{pH} 7.4)$ in an atmosphere of $5 \% \mathrm{CO}_{2}$ at $37^{\circ} \mathrm{C}$.

$\mathrm{SO}_{2}$ derivatives. $\mathrm{SO}_{2}$ is mainly derived from sulfite $\left(\mathrm{SO}_{3}^{2-}\right)$ and bisulfite $\left(\mathrm{HSO}_{3}^{-}\right.$) generated after $\mathrm{SO}_{2}$ dissolves in cellular cytoplasm. ${ }^{50} \mathrm{SO}_{2}$ can easily be hydrated to produce sulfurous acid, which subsequently dissociates to form its derivatives, $\mathrm{SO}_{3}^{2-}$ and $\mathrm{HSO}_{3}^{-}\left(3: 1\right.$ mole ratios in neutral fluids). ${ }^{28}$ Therefore, a combination of $\mathrm{Na}_{2} \mathrm{SO}_{3}$ and $\mathrm{NaHSO}_{3}$ (3:1 mole ratios; Sigma-Aldrich, St. Louis, $\mathrm{MO}, \mathrm{USA}$ ) was used as $\mathrm{SO}_{2}$ derivatives in the experiments. ${ }^{28,34}$

Overexpression of AAT1 or AAT2 in VSMCs. The CDNA fragment encoding the full-length rat AAT1 (NM_012571.2) or AAT2 (NM_013177.2) was amplified by PCR and inserted into the pIRES2-EGFP vector, and the resultant plasmid AAT1 or AAT2 was verified by DNA sequencing. A7r5 VSMCs were then transfected with AAT1, AAT2 or vehicle plasmid using JetPEI reagent according to the manufacturer's instructions (Polyplus Transfection, Illkirch, France).

Knockdown of AAT1 or AAT2 in VSMCs. Rat AAT1 shRNA and AAT2 shRNA were from OriGene Technologies (Rockville, MD, USA). A7r5 VSMCs were transfected with AAT1 shRNA, AAT2 shRNA or control shRNA using JetPEI reagent according to the manufacturer's instructions.

Determination of AAT1 and AAT2 mRNA expressions by quantitative real-time polymerase chain reaction. Total RNA was extracted using the Trizol reagent and transcribed into cDNA using oligo (dT)15 primer and M-MLV reverse transcriptase. Quantitative real-time polymerase chain reaction (RT-PCR) was performed on an ABI PRISM 7300 instrument (Applied Biosystems, Foster, CA, USA). The amplification conditions for the cDNA for AAT1 and AAT2 were: denaturing at $94^{\circ} \mathrm{C}$ for $15 \mathrm{~s}$, annealing at $60^{\circ} \mathrm{C}$ for $1 \mathrm{~min}$ and polymerizing at $72{ }^{\circ} \mathrm{C}$ for $30 \mathrm{~s}$ for 40 cycles. Samples and standards were determined in duplicate. TaqMan probes were modified by $5^{\prime}$-FAM and $3^{\prime}$-TAMRA. The primers used for rat AAT1 were: $5^{\prime}$-CCAGGGAGCTCGGATCGT-3' (sense) and $5^{\prime}$-GCCATTGTCTTCACGTTTCCTT- $3^{\prime}$ (antisense) and the expected product length was 79 base pairs. The primers for rat AAT2 were: $5^{\prime}$-GAGGGTCGGAGCC AGCTT-3' (sense) and $5^{\prime}$-GTTTCCCCAGGATGGTTTGG-3' (antisense), and the expected product length was 82 base pairs. $\beta$-Actin was used for normalization. The $5^{\prime}$ and $3^{\prime}$ primers for $\beta$-actin were: $5^{\prime}$-ACCCGCGAGTACAACCTTCTT- $3^{\prime}$ and $5^{\prime}$-TATCGTCATCCATGGCGAACT-3', respectively, and the expected product length was 80 base pairs.

Evaluation of the viability and proliferation of VSMCs. The viability and proliferation of VSMCs were evaluated using the CCK-8 assay (Dojindo Molecular Technologies, Kumamoto, Japan). Briefly, $1 \times 10^{3}$ cells per well were seeded in 96-well plates, starved in low-serum $(0.5 \%$ FBS) medium for $24 \mathrm{~h}$, treated with or without $10 \% \mathrm{FBS}$ and $\mathrm{Na}_{2} \mathrm{SO}_{3} / \mathrm{NaHSO}_{3}$ (Sigma-Aldrich) at indicated concentrations for $24 \mathrm{~h}$ and incubated with CCK-8 solution for $1 \mathrm{~h}$. The absorbance was then measured at $450 \mathrm{~nm}$ using a microplate reader (Bio-Rad, Richmond, CA, USA).

VSMCs $\left(1 \times 10^{3}\right.$ per well) in 96-well plates were starved in low-serum medium for $24 \mathrm{~h}$, and treated with $\mathrm{H}-89$ (Cell Signaling Technology, Danvers, MA, USA) at $20 \mu \mathrm{mol} / /, \mathrm{Na}_{2} \mathrm{SO}_{3} / \mathrm{NaHSO}_{3}$ at $15 \mu \mathrm{mol} / /$ and PDGF-BB (Peprotech, Rocky Hill, NJ, USA) at $50 \mathrm{ng} / \mathrm{ml}$ for $24 \mathrm{~h}$. The proliferative levels were then assessed by CCK- 8 assay.

Cell growth curve. Equal numbers $\left(5 \times 10^{3}\right)$ of VSMCs were plated into 24-well tissue culture dishes and cell numbers were determined by a TC-10 automated cell counter (Bio-Rad). Countings were made at 24, 48 and $72 \mathrm{~h}$ of cells with different doses of $\mathrm{Na}_{2} \mathrm{SO}_{3} / \mathrm{NaHSO}_{3}$ treatments. Triplicate plates were used for each time point.

Flow cytometry. VSMCs were starved in low-serum medium for $24 \mathrm{~h}$, and then cultured in DMEM with $0.5 \% \mathrm{FBS}$, in medium with $10 \% \mathrm{FBS}$ and/or treated with $\mathrm{Na}_{2} \mathrm{SO}_{3} / \mathrm{NaHSO}_{3}$ at indicated concentrations for $24 \mathrm{~h}$. Samples were harvested and fixed in $70 \%$ ethanol overnight at $-20^{\circ} \mathrm{C}$. Before measurement, cells were incubated in PBS containing $100 \mu \mathrm{g} / \mathrm{ml}$ RNase A at $37^{\circ} \mathrm{C}$ for $30 \mathrm{~min}$, stained with $50 \mu \mathrm{g} / \mathrm{ml} \mathrm{PI}$ for $10 \mathrm{~min}$ and then analyzed by flow cytometry
(Becton-Dickinson, Franklin Lakes, NJ, USA). Results are expressed as the percentage of cells in each cell cycle phase for cell cycle analysis.

BrdU incorporation assay. VSMCs were seeded on coverslips in 6-well plates to $60-70 \%$ confluences before they were made quiescent in DMEM containing $0.5 \%$ FBS for $24 \mathrm{~h}$. Immunofluorescence assay was then used for the detection of BrdU incorporated into cellular DNA (BrdU Labeling and Detection Kit I, Roche, Penzberg, Germany). Then, cells were incubated in BrdU labeling reagent (final concentration $10 \mu \mathrm{mol} / \mathrm{l}$ ) while cultured in: (1) medium with $0.5 \% \mathrm{FBS}$, medium with $10 \% \mathrm{FBS}$ and with $\mathrm{Na}_{2} \mathrm{SO}_{3} / \mathrm{NaHSO}_{3}$ at $5,10,15$ and $20 \mu \mathrm{mol} / / \mathrm{l}$ for $24 \mathrm{~h}$; and (2) medium with $0.5 \% \mathrm{FBS}$, medium with $0.5 \% \mathrm{FBS}$ and with PDGF-BB at $50 \mathrm{ng} / \mathrm{ml}$, and medium with $0.5 \%$ FBS, PDGF-BB at $50 \mathrm{ng} / \mathrm{ml}$ and $\mathrm{Na}_{2} \mathrm{SO}_{3} /$ $\mathrm{NaHSO}_{3}$ at $15 \mu \mathrm{mol} / /$ for $24 \mathrm{~h}$. The immunofluorescence detection was complied with the manufacturer's instructions. Total cellular nuclei were stained with PI. The results were reported as a percentage of BrdU-labelled cells to the total amount of cells.

In another model, A7r5 cells $\left(5 \times 10^{4}\right)$ were incubated in 6 -well plates. When cells were grown to $60-70 \%$ confluences, they were transfected with $2 \mu \mathrm{g} \mathrm{AAT1}$, AAT2 or vehicle plasmid using JetPEI reagent according to the manufacturer's instructions. After $24 \mathrm{~h}$, they were starved in DMEM containing $0.5 \%$ FBS for another $24 \mathrm{~h}$. Then, cells were incubated in BrdU labeling reagent while cultured in medium with $0.5 \%$ FBS or medium with $10 \%$ FBS for $24 \mathrm{~h}$. The immunofluorescence detection was described above.

Overexpression of MEK in HEK293 cells. MEK1 overexpression plasmids, wild-type and CA types, were constructed as described, ${ }^{51}$ using pIRES2-EGFP as the vector. After transfected with the vector, the MEK wild-type plasmid, CA-MEK S218E-S222D plasmid, CA-MEK $\triangle N 3$ plasmid and the CA-MEK $\triangle$ N3-S218E-S222D plasmid HEK293 cells in the experimental groups were treated with $\mathrm{Na}_{2} \mathrm{SO}_{3} / \mathrm{NaHSO}_{3}$ at $15 \mu \mathrm{mol} / /$ for $24 \mathrm{~h}$. The phosphorylation of Erk1/2 was evaluated by western blotting.

c-Raf kinase activity assay. VSMCs were cultured in DMEM with $10 \%$ FBS. Cytoplasmic proteins were then extracted in non-denaturing lysis buffer. The sample was divided evenly into six groups to estimate c-Raf (Raf-1) activity at different doses of $\mathrm{Na}_{2} \mathrm{SO}_{3} / \mathrm{NaHSO}_{3}$. Raf-1 Kinase Assay Kit with Chemiluminescence Detection (Millipore, Billerica, MA, USA) was used according to the manufacturer's instructions. $\mathrm{Na}_{2} \mathrm{SO}_{3} / \mathrm{NaHSO}_{3}$ was added before adding inactive MEK1. c-Raf kinase activity was represented as the phosphorylation of recombinant inactive MEK1 after c-Raf kinase reaction by western blotting analysis.

Another part of c-Raf activity assay was on different reagents interfering whole VSMCs. After $24 \mathrm{~h}$ low-serum starvation, cells were divided into four groups: (1) control; (2) with PDGF-BB $20 \mathrm{ng} / \mathrm{ml}$ for $30 \mathrm{~min}$; (3) pretreated with $\mathrm{Na}_{2} \mathrm{SO}_{3} / \mathrm{NaHSO}_{3}$ at $15 \mu \mathrm{mol} / /$ for $30 \mathrm{~min}$ and then with PDGF-BB $20 \mathrm{ng} / \mathrm{ml}$ for $30 \mathrm{~min}$; and (4) with $\mathrm{Na}_{2} \mathrm{SO}_{3} / \mathrm{NaHSO}_{3}$ at $15 \mu \mathrm{mol} / / \mathrm{l}$ for $30 \mathrm{~min}$. Samples were lysed as described above and $\mathrm{c}$-Raf activity was assessed technically conforming to the manufacturer's protocol.

Western blotting analysis. A7r 5 cells $\left(5 \times 10^{4}\right)$ were incubated in 6-well plates. When cells were grown to $60-70 \%$ confluences, they were starved in lowserum $(0.5 \% \mathrm{FBS})$ medium for $24 \mathrm{~h}$.

In the first series, cells were pretreated with or without $\mathrm{Na}_{2} \mathrm{SO}_{3} / \mathrm{NaHSO}_{3}$ at $15 \mu \mathrm{mol} / \mathrm{l}$ for $30 \mathrm{~min}$, and then with PDGF-BB at $50 \mathrm{ng} / \mathrm{ml}$ for $24 \mathrm{~h}$.

In the second series, cells were divided into four groups: (1) untreated; (2) with PDGF-BB $20 \mathrm{ng} / \mathrm{ml}$ for $30 \mathrm{~min}$; (3) pretreated with $\mathrm{Na}_{2} \mathrm{SO}_{3} / \mathrm{NaHSO}_{3}$ at $15 \mu \mathrm{mol} / \mathrm{l}$ for $30 \mathrm{~min}$ and then with PDGF-BB $20 \mathrm{ng} / \mathrm{ml}$ for $30 \mathrm{~min}$; and (4) with $\mathrm{Na}_{2} \mathrm{SO}_{3} / \mathrm{NaHSO}_{3}$ at $15 \mu \mathrm{mol} / \mathrm{l}$ for $30 \mathrm{~min}$.

In the third series, cells were divided into five groups: (1) untreated; (2) treated with $\mathrm{Na}_{2} \mathrm{SO}_{3} / \mathrm{NaHSO}_{3}$ at $15 \mu \mathrm{mol} / /$ for $30 \mathrm{~min}$; (3) treated with Forskolin (Cell Signaling Technology) at $30 \mu \mathrm{mol} / /$ for $30 \mathrm{~min}$; (4) treated with $\mathrm{H}-89$ at $20 \mu \mathrm{mol} / / \mathrm{l}$ for $30 \mathrm{~min}$; and (5) pretreated with $\mathrm{H}-89$ at $20 \mu \mathrm{mol} / / \mathrm{l}$ for 20 min followed by $\mathrm{Na}_{2} \mathrm{SO}_{3} /$ $\mathrm{NaHSO}_{3}$ at $15 \mu \mathrm{mol} / \mathrm{l}$ for $30 \mathrm{~min}$.

All samples were harvested and lysed in lysis buffer $(0.5 \mathrm{mmol} / \mathrm{IEDTA}, 10 \mathrm{mmo} / /$ Tris- $\mathrm{HCl}, \mathrm{pH} 7.4,0.3 \mathrm{~mol} / \mathrm{l}$ sucrose and protease inhibitor cocktail) as described previously. ${ }^{14}$ Equal amounts of protein were resolved on SDS-PAGE gels and transferred onto nitrocellulose membranes. Nonspecific bindings were blocked by incubation in 5\% milk blocking buffer. The primary antibodies anti-cyclin D1, anti-c-Raf, anti-phospho-c-Raf (Ser338), anti-phospho-c-Raf (Ser259), phosphorMEK1/2 (Ser217/221), phosphor-Erk1/2 (Thr202/Tyr204), and anti-PKA and 
anti-phospho-PKA (Thr197) were all from Cell Signaling Technology; anti-phosphoc-Raf (Ser43) was from Abcam (Cambridge, MA, USA); anti-Erk1/2 and antiGAPDH were from Kangcheng (Shanghai, China); and MEK1/2 and anti- $\beta$-actin were from Santa Cruz Biotechnology (Santa Cruz, CA, USA). After incubation, each primary antibody bound with their respective specific horseradish peroxidaseconjugated secondary antibodies (Santa Cruz Biotechnology) and the bands were visualized using Enhanced Chemiluminescence Detection Kit (Thermo Scientific, Rockford, IL, USA). The densitometric analysis of the positive bands was performed using AlphaEaseFC (Alpha Innotech Corporation, San Leandro, CA, USA).

A7r5 cells $\left(5 \times 10^{4}\right)$ were incubated in 6 -well plates. When cells were grown to $60-70 \%$ confluences, they were transfected with $2 \mu \mathrm{g}$ of AAT1, AAT2 or vehicle plasmid using JetPEI reagent according to the manufacturer's instructions. After $24 \mathrm{~h}$, they were starved in DMEM with $0.5 \%$ FBS before serum (10\% FBS) treatment for $24 \mathrm{~h}$. Then, these samples were harvested and lysed in lysis buffer for western blot analysis. The primary antibody dilutions were: 1:500 for AAT1, $1: 5000$ for AAT2 and $1: 2000$ for PCNA, respectively.

Measurements of cAMP concentrations in VSMCs. A7r5 cells $\left(5 \times 10^{4}\right)$ were incubated in 6 -well plates. When the cells were grown to $70-80 \%$ confluences, they were starved in low-serum $(0.5 \% \mathrm{FBS})$ medium for $24 \mathrm{~h}$. VSMCs were divided into five groups: (1) untreated; (2) treated with $\mathrm{Na}_{2} \mathrm{SO}_{3} / \mathrm{NaHSO}_{3}$ at $15 \mu \mathrm{mol} / / \mathrm{l}$ for $30 \mathrm{~min}$; (3) treated with Forskolin at $30 \mu \mathrm{mol} / / \mathrm{l}$ for $30 \mathrm{~min}$; (4) treated with $\mathrm{H}-89$ at $20 \mu \mathrm{mol} / \mathrm{l}$ for $30 \mathrm{~min}$; and (5) pretreated with $\mathrm{H}-89$ at $20 \mu \mathrm{mol} / / \mathrm{l}$ for $20 \mathrm{~min}$, followed by $\mathrm{Na}_{2} \mathrm{SO}_{3} / \mathrm{NaHSO}_{3}$ at $15 \mu \mathrm{mol} / \mathrm{l}$ for $30 \mathrm{~min}$. Cells were immediately lysed in $0.1 \mathrm{~mol} / /$ hydrochloric acid, while the culture medium could also be treated with hydrochloric acid for sample preparation. The cAMP concentrations were assessed using an ELISA-based assay (CAMP Enzyme Immunoassay Kit, Direct; Sigma-Aldrich), according to the manufacturer's instructions. All standards and samples were run in duplicate and read in the optical density at $405 \mathrm{~nm}$ with correction at $590 \mathrm{~nm}$ by an ELISA reader (Bio-Rad), and the cAMP concentrations of samples (pmol/l) were calculated from the standard curve.

Statistical analysis. Results were presented as mean \pm S.D. Statistical comparisons were performed with SPSS 13.0 software (SPSS, Chicago, IL, USA). Comparison between two groups was performed using two-tailed independent $t$-test. Comparisons among more than two groups involved one-way ANOVA followed by the Student-Newman-Keuls test for post hoc comparison as appropriate. Two-way ANOVA followed by the Bonferroni test for comparisons between groups was performed in analyzing the effect of $\mathrm{SO}_{2}$ derivatives at different concentrations on serum-stimulated VSMC proliferation over time. At least three different samples or independent experiments, each in triplicate, were analyzed in each group. $P<0.05$ was considered significant.

\section{Conflict of Interest}

The authors declare no conflict of interest.

Acknowledgements. This study was supported by National Natural Science Foundation of China (No. 31130030), Major Basic Research Program of China (No. 2012CB517806) and National Natural Science Foundation of China (No. 81121061).

\section{Author contributions}

$\mathrm{DL}$ and $\mathrm{YH}$ designed and performed the experiments, analyzed the data and prepared the figures. DB, ADL and LH provided the VSMCs, constructed the plasmids and contributed new analytical reagents and tools. YJ performed the experiments, analyzed the data and prepared the figures. CT, JD and HJ obtained funding, designed the study and wrote the manuscript. All authors read and approved the final manuscript.

1. Owens GK, Kumar MS, Wamhoff BR. Molecular regulation of vascular smooth muscle cell differentiation in development and disease. Physiol Rev 2004; 84: 767-801.

2. Liu WF, Nelson CM, Tan JL, Chen CS. Cadherins RhoA, and Rac1 are differentially required for stretch-mediated proliferation in endothelial versus smooth muscle cells. Circ Res 2007; 101: e44-e52.

3. Nelson CM, Chen CS. Cell-cell signaling by direct contact increases cell proliferation via a PI3K-dependent signal. FEBS Lett 2002; 514: 238-242.
4. Kawada M, Yamagoe S, Murakami Y, Suzuki K, Mizuno S, Uehara Y. Induction of p27Kip1 degradation and anchorage independence by Ras through the MAP kinase signaling pathway. Oncogene 1997; 15: 629-637.

5. Lavoie JN, L'Allemain G, Brunet A, Muller R, Pouyssegur J. Cyclin D1 expression is regulated positively by the p42/p44MAPK and negatively by the p38/HOGMAPK pathway. J Biol Chem 1996; 271: 20608-20616.

6. Palmer A, Gavin AC, Nebreda AR. A link between MAP kinase and p34(cdc2)/cyclin B during oocyte maturation: $\mathrm{p} 90$ (rsk) phosphorylates and inactivates the $\mathrm{p34}$ (cdc2) inhibitory kinase Myt1. EMBO J 1998; 17: 5037-5047.

7. Pacheco TR, Moita LF, Gomes AQ, Hacohen N, Carmo-Fonseca M. RNA interference knockdown of hU2AF35 impairs cell cycle progression and modulates alternative splicing of Cdc25 transcripts. Mol Biol Cell 2006; 17: 4187-4199.

8. Bryan NS, Bian K, Murad F. Discovery of the nitric oxide signaling pathway and targets for drug development. Front Biosci 2009; 14: 1-18.

9. Erusalimsky JD, Moncada S. Nitric oxide and mitochondrial signaling: from physiology to pathophysiology. Arterioscler Thromb Vasc Biol 2007; 27: 2524-2531.

10. Wang R. Two's company, three's a crowd: can $\mathrm{H} \cdot \mathrm{S}$ be the third endogenous gaseous transmitter? FASEB J 2002; 16: 1792-1798.

11. Kimura $H$, Shibuya $N$, Kimura $Y$. Hydrogen sulfide is a signaling molecule and a cytoprotectant. Antioxid Redox Signal 2012; 17: 45-57.

12. Liu YH, Lu M, Hu LF, Wong PT, Webb GD, Bian JS. Hydrogen sulfide in the mammalian cardiovascular system. Antioxid Redox Signal 2012; 17: 141-185.

13. Meng QH, Yang G, Yang W, Jiang B, Wu L, Wang R. Protective effect of hydrogen sulfide on balloon injury-induced neointima hyperplasia in rat carotid arteries. Am J Pathol 2007; 170: $1406-1414$

14. Yang G, Pei Y, Teng H, Cao Q, Wang R. Specificity protein-1 as a critical regulator of human cystathionine gamma-lyase in smooth muscle cells. J Biol Chem 2011; 286: 26450-26460.

15. Yang G, Wu L, Bryan S, Khaper N, Mani S, Wang R. Cystathionine gamma-lyase deficiency and overproliferation of smooth muscle cells. Cardiovasc Res 2010; 86: 487-495.

16. Du J, Hui $Y$, Cheung $Y, B i n ~ G$, Jiang $H$, Chen $X$ et al. The possible role of hydrogen sulfide as a smooth muscle cell proliferation inhibitor in rat cultured cells. Heart Vessels 2004; 19: 75-80.

17. Yang $G$, Sun $X$, Wang $R$. Hydrogen sulfide-induced apoptosis of human aorta smooth muscle cells via the activation of mitogen-activated protein kinases and caspase-3. FASEB J 2004; 18: 1782-1784.

18. Baskar R, Bian J. Hydrogen sulfide gas has cell growth regulatory role. Eur J Pharmacol 2011; 656: 5-9.

19. Griffith OW. Mammalian sulfur amino acid metabolism: an overview. Methods Enzymol 1987; 143: 366-376.

20. Stipanuk MH. Sulfur amino acid metabolism: pathways for production and removal of homocysteine and cysteine. Annu Rev Nutr 2004; 24: 539-577.

21. Kimura H. Hydrogen sulfide: its production and functions. Exp Physiol 2011; 96: 833-835.

22. Hayashi S, Morishita R, Matsushita H, Nakagami H, Taniyama Y, Nakamura T et al. Cyclic AMP inhibited proliferation of human aortic vascular smooth muscle cells, accompanied by induction of p53 and p21. Hypertension 2000; 35: 237-243.

23. Graves LM, Bornfeldt KE, Raines EW, Potts BC, Macdonald SG, Ross R et al. Protein kinase $A$ antagonizes platelet-derived growth factor-induced signaling by mitogen-activated protein kinase in human arterial smooth muscle cells. Proc Natl Acad Sci USA 1993; 90: 10300-10304.

24. Osinski MT, Schror K. Inhibition of platelet-derived growth factor-induced mitogenesis by phosphodiesterase 3 inhibitors: role of protein kinase $A$ in vascular smooth muscle cell mitogenesis. Biochem Pharmacol 2000; 60: 381-387.

25. Balmanno K, Millar T, McMahon M, Cook SJ. DeltaRaf-1:ER* bypasses the cyclic AMP block of extracellular signal-regulated kinase 1 and 2 activation but not CDK2 activation or cell cycle reentry. Mol Cell Biol 2003; 23: 9303-9317.

26. Dumaz N, Light Y, Marais R. Cyclic AMP blocks cell growth through Raf-1-dependent and Raf-1-independent mechanisms. Mol Cell Biol 2002; 22: 3717-3728.

27. Sidovar MF, Kozlowski P, Lee JW, Collins MA, He Y, Graves LM. Phosphorylation of serine 43 is not required for inhibition of c-Raf kinase by the cAMP-dependent protein kinase. J Biol Chem 2000; 275: 28688-28694.

28. Meng Z, Li Y, Li J. Vasodilatation of sulfur dioxide derivatives and signal transduction. Arch Biochem Biophys 2007; 467: 291-296.

29. Singer TP, Kearney EB. Intermediary metabolism of L-cysteine sulfinic acid in animal tissues. Arch Biochem Biophys 1956; 61: 397-409.

30. Balazy M, Abu-Yousef IA, Harpp DN, Park J. Identification of carbonyl sulfide and sulfur dioxide in porcine coronary artery by gas chromatography/mass spectrometry, possible relevance to EDHF. Biochem Biophys Res Commun 2003; 311: 728-734.

31. Sardesai VM. Molybdenum: an essential trace element. Nutr Clin Pract 1993; 8: 277-281.

32. Luo L, Chen S, Jin H, Tang C, Du J. Endogenous generation of sulfur dioxide in rat tissues. Biochem Biophys Res Commun 2011; 415: 61-67.

33. Du SX, Jin HF, Bu DF, Zhao X, Geng B, Tang CS et al. Endogenously generated sulfur dioxide and its vasorelaxant effect in rats. Acta Pharmacol Sin 2008; 29: 923-930.

34. Sun Y, Tian Y, Prabha M, Liu D, Chen S, Zhang R et al. Effects of sulfur dioxide on hypoxic pulmonary vascular structural remodeling. Lab Invest 2010; 90: 68-82.

35. Chi JT, Rodriguez EH, Wang Z, Nuyten DS, Mukherjee S, van de Rijn M et al. Gene expression programs of human smooth muscle cells: tissue-specific differentiation and prognostic significance in breast cancers. PLOS Genet 2007; 3: 1770-1784. 
36. Benditt EP, Benditt JM. Evidence for a monoclonal origin of human atherosclerotic plaques. Proc Natl Acad Sci USA 1973; 70: 1753-1756.

37. Frid MG, Moiseeva EP, Stenmark KR. Multiple phenotypically distinct smooth muscle cell populations exist in the adult and developing bovine pulmonary arterial media in vivo. Circ Res 1994; 75: 669-681.

38. Hao H, Ropraz P, Verin V, Camenzind E, Geinoz A, Pepper MS et al. Heterogeneity of smooth muscle cell populations cultured from pig coronary artery. Arterioscler Thromb Vasc Biol 2002; 22: 1093-1099.

39. Garvalov BK, Higgins TE, Sutherland JD, Zettl M, Scaplehorn N, Kocher T et al. The conformational state of Tes regulates its zyxin-dependent recruitment to focal adhesions. J Cell Biol 2003; 161: 33-39.

40. Raines EW. PDGF and cardiovascular disease. Cytokine Growth Factor Rev 2004; 15 : 237-254.

41. Baccarini M. Second nature: biological functions of the Raf-1 'kinase'. FEBS Lett 2005; 579: 3271-3277.

42. Takakuwa Y, Pack CG, An XL, Manno S, Ito E, Kinjo M. Fluorescence correlation spectroscopy analysis of the hydrophobic interactions of protein 4.1 with phosphatidyl serine liposomes. Biophys Chem 1999; 82: 149-155.

43. Dumaz N, Marais $R$. Integrating signals between cAMP and the RAS/RAF/MEK/ERK signalling pathways. Based on the anniversary prize of the Gesellschaft fur Biochemie und Molekularbiologie Lecture delivered on 5 July 2003 at the Special FEBS Meeting in Brussels. FEBS J 2005; 272: 3491-3504.

44. Wu J, Dent P, Jelinek T, Wolfman A, Weber MJ, Sturgill TW. Inhibition of the EGF-activated MAP kinase signaling pathway by adenosine 3',5'-monophosphate. Science 1993; 262: 1065-1069.

45. Michaud NR, Fabian JR, Mathes KD, Morrison DK. 14-3-3 is not essential for Raf-1 function: identification of Raf-1 proteins that are biologically activated in a 14-3-3- and Ras-independent manner. Mol Cell Biol 1995; 15: 3390-3397.
46. Yaffe MB. How do 14-3-3 proteins work? - Gatekeeper phosphorylation and the molecular anvil hypothesis. FEBS Lett 2002; 513: 53-57.

47. Dumaz N, Marais R. Protein kinase A blocks Raf-1 activity by stimulating 14-3-3 binding and blocking Raf-1 interaction with Ras. J Biol Chem 2003; 278: 29819-29823.

48. Dhillon AS, Pollock C, Steen H, Shaw PE, Mischak H, Kolch W. Cyclic AMP-dependent kinase regulates Raf-1 kinase mainly by phosphorylation of serine 259. Mol Cell Biol 2002; 22: 3237-3246.

49. Light Y, Paterson H, Marais R. 14-3-3 Antagonizes Ras-mediated Raf-1 recruitment to the plasma membrane to maintain signaling fidelity. Mol Cell Biol 2002; 22: 4984-4996.

50. Madamanchi NR, Alscher RG. Metabolic bases for differences in sensitivity of two pea cultivars to sulfur dioxide. Plant Physiol 1991; 97: 88-93.

51. Mansour SJ, Matten WT, Hermann AS, Candia JM, Rong S, Fukasawa K et al. Transformation of mammalian cells by constitutively active MAP kinase kinase. Science 1994; 265: 966-970.

(i) $(-)$ Cell Death and Disease is an open-access journal published by Nature Publishing Group. This work is licensed under a Creative Commons Attribution-NonCommercialNoDerivs 3.0 Unported License. The images or other third party material in this article are included in the article's Creative Commons license, unless indicated otherwise in the credit line; if the material is not included under the Creative Commons license, users will need to obtain permission from the license holder to reproduce the material. To view a copy of this license, visit http://creativecommons.org/ licenses/by-nc-nd/3.0/ 